\title{
Characterization of a novel thermostable and xylose-tolerant GH $39 \beta$-xylosidase from Dictyoglomus thermophilum
}

\author{
Qi Li ${ }^{1,2,3}$, Tao $\mathrm{Wu}^{2}$, Zhipeng $\mathrm{Qi}^{2}$, Linguo Zhao ${ }^{1,2,3^{*}}$, Jianjun Pei ${ }^{2,3}$ and Feng Tang ${ }^{4}$
}

\begin{abstract}
Background: $\beta$-D-xylosidase is a vital exoglycosidase with the ability to hydrolyze xylooligosaccharides to xylose and to biotransform some saponins by cleaving outer $\beta$-xylose. $\beta$-D-xylosidase is widely used as one of the xylanolytic enzymes in a diverse range of applications, such as fuel, food and the pharmaceutical industry; therefore, more and more studies have focused on the thermostable and xylose-tolerant $\beta$-D-xylosidases.

Results: A thermostable $\beta$-xylosidase gene (x/n-DT) of 1509 bp was cloned from Dictyoglomus thermophilum and expressed in E.coli BL21. According to the amino acid and phylogeny analyses, the $\beta$-xylosidase XIn-DT is a novel $\beta$ xylosidase of the GH family 39 . The recombinant $\beta$-xylosidase was purified, showing unique bands on SDS-PAGE, and had a protein molecular weight of $58.7 \mathrm{kDa}$. The $\beta$-xylosidase XIn-DT showed an optimal activity at pH 6.0 and $75^{\circ} \mathrm{C}$, with $\mathrm{p}$-nitrophenyl- $\beta$-D-xylopyranoside (pNPX) as a substrate. XIn-DT displayed stability over a pH range of 4.0-7.5 for $24 \mathrm{~h}$ and displayed thermotolerance below $85^{\circ} \mathrm{C}$. The values of the kinetic parameters $K_{m}$ and $V_{\text {max }}$ for pNPX were 1. $66 \mathrm{mM}$ and $78.46 \mathrm{U} / \mathrm{mg}$, respectively. In particular, XIn-DT displayed high tolerance to xylose, with $60 \%$ activity in the presence of $3 \mathrm{M}$ xylose. XIn-DT showed significant effects on the hydrolyzation of xylobiose. After $3 \mathrm{~h}$, all the xylobiose tested was degraded into xylose. Moreover, $\beta$-xylosidase XIn-DT had a high selectivity for cleaving the outer xylose moieties of natural saponins, such as notoginsenoside R1 and astragaloside IV, which produced the ginsenoside Rg1 with stronger anti-fatigue activity and produced cycloastragenol with stronger anti-aging activity, respectively.
\end{abstract}

Conclusion: This study provides a novel GH 39 ß-xylosidase displaying extraordinary properties of highly catalytic activity at temperatures above $75^{\circ} \mathrm{C}$, remarkable hydrolyzing activity of xylooligosaccharides and rare saponins producing ability in the pharmaceutical and commercial industries.

Keywords: Dictyoglomus thermophilum, $\beta$-xylosidase, Xylose tolerant, Xylooligosaccharides, Biotransformation

\section{Background}

Recently, more and more studies have focused on cellulose and hemicellulose hydrolysis in an effort to use lignocellulosic residues as feedstock for producing bioethanol $[1,2]$. The plant cell wall mainly consists of $30-45 \%$ cellulose, $20-30 \%$ hemicellulose and 5-20\% lignin [3]. Hemicelluloses, as the second most abundant renewable lignocellulosic biomass resource, are a series of heteropolysaccharides that contain xylans, arabinans, glucans and

\footnotetext{
*Correspondence: njfu2304@163.com

${ }^{1}$ Co-Innovation Center for Sustainable Forestry in Southern China, Nanjing Forestry University, 159 Long Pan Road, Nanjing 210037, China

${ }^{2}$ College of Chemical Engineering, Nanjing Forestry University, 159 Long Pan

Road, Nanjing 210037, China

Full list of author information is available at the end of the article
}

mannans, in which xylan is the major hemicellulosic polysaccharide that can be efficiently hydrolyzed into its sugar constituents [4-6]. The xylan backbone consists of $\beta$ $(1,4)$-linked xylopyranosyl units with side-chains, such as acetate, glucuronosyl and arabinofuranosyl depending on the source. Complete xylan degradation requires the concerted action of xylanolytic enzymes, owing to the complex structure. First, xylanase randomly cleaves the $\beta-1,4$ bonds in the xylan to yield xylooligosaccharides (XOs), xylobiose and xylose [7]. Second, $\alpha$-arabinofuranosidase, acetylesterase, $\alpha$-glucuronidase and ferulic acid esterase cleave the side-chain substituents [8]. In the last step, $\beta$ xylosidase, which is well known as the major hydrolytic enzyme that degrades the non-reducing ends of $\beta-1,4-$ linked D-xylose residues to release xylose as the final

(c) The Author(s). 2018 Open Access This article is distributed under the terms of the Creative Commons Attribution 4.0 International License (http://creativecommons.org/licenses/by/4.0/), which permits unrestricted use, distribution, and 
product from short xylooligosaccharides $[9,10]$. However, the roles of $\beta$-xylosidase include, but are not limited to, the degradation of xylooligosaccharide. $\beta$-xylosidase has large potential in many biotechnological applications, especially in the fuel and food industries as well as the bioconversion of saponins [11-13].

Saponin is a kind of bioactive substance with a range of physiological functions, such as anti-inflammatory, anti-cancer, immunoregulatory and anti-fatigue effects $[14,15]$. Various saponins have disparate physiological activities as a result of diverse skeletons and sugar moieties. Thus, many studies have concentrated more on biotransforming glycosylated saponins to deglycosylated saponins by removing the sugar moieties with enzymes, such as $\beta$-glucosidase and $\alpha$-rhamnosidase, to achieve better pharmacological effects $[16,17]$. Furthermore, part of the saponins are needed to hydrolyze the xylose moiety by $\beta$-xylosidases. Unfortunately, until recently, it has been difficult to find a highly thermostable recombinant $\beta$ xylosidase with the ability to convert saponins. Ginsenoside Rg1 (Rg1) and cycloastragenol (CA) are the major bioactive constituents in the plants Panax notoginseng and Astragali radix, respectively [18, 19], which have been considered to be remarkable ingredients with pharmacological activities [20, 21]. Chinese Pharmacopoeia (Edition 2015) has used $\operatorname{Rg} 1$ as the major index component for the Quality Control (QC) of ginseng herbs [22]. However, it is quite difficult to improve the purity of the exact quantification of Rg1 because there are many homologous components with highly similar physicochemical properties from the target compound. Therefore, conversion from notoginsenoside $\mathrm{R} 1$ to $\mathrm{Rg} 1$ can greatly improve the purity of Rg1 [12]. CA, as the aglycone of astragaloside IV (ASI), can activate telomerase, which displays great potential for anti-aging activity [23]. Nevertheless, it is very difficult to isolate CA from Astragali radix due to its low concentration. Therefore, conversion from ASI to CA could increase the content of CA efficiently. Methods such as acid hydrolysis, heating treatment, steaming treatment, and microbial and enzymatic transformation, have been used to convert these saponins [24-26]. Among these methods, enzymatic transformation with $\beta$-xylosidase has exhibited potential because of its mild reaction condition and high specificity.

As is well known, $\beta$-xylosidases are largely found in GH families $1,3,30,39,43,52,54$ and 120 , according to the GH classification system CAZy (Carbonhydrate-Active Enzymes Database) [27]. Until recently, many $\beta$-xylosidases from different $\mathrm{GH}$ families have been described in a variety of microorganisms including bacteria, archaea, fungi and plant [28-31]. Generally, xylosidases from fungal sources have optimum $\mathrm{pH}$ values from 3 to 5 and an optimum temperature range from $40{ }^{\circ} \mathrm{C}$ to $60{ }^{\circ} \mathrm{C}$, thus far, these xylosidases have only been grouped into GH 3, GH 43 and GH 54 [32, 33]. Literature about the extremely thermophilic and xylosetolerant $\beta$-xylosidases is relatively scarce. Therefore, thermophilic bacteria are regarded as a remarkable source of thermotolerant $\beta$-xylosidases [34-36]. Usually, $\beta$-xylosidases with thermostability, greater specific activity and a greater tolerance to xylose are used in industrial processes, since high temperatures increase the solubility of substrates and reduce the risk of contamination, and the resistance to xylose can reduce the inhibition of substrate feedback [37]. As a result, the search for thermostable and xylose-tolerant $\beta$-xylosidases has increased considerably in recent years.

In this article, we cloned, expressed and characterized a novel thermostable GH $39 \beta$-xylosidase from Dictyoglomus thermophilum DSM 3960. In particular, the high tolerance to xylose makes this $\beta$-xylosidase useful for various biotechnological applications. Moreover, this enzyme exhibited highly selective hydrolysis for outer xylose in notoginsenoside R1 and CA. These extraordinary properties make Xln-DT more suitable for producing rare saponins in the pharmaceutical and commercial industries.

\section{Methods}

\section{Bacterial strains, plasmids and materials}

Dictyoglomus thermophilum DSM 3960 was purchased from DSMZ (www.dsmz.de). The E. coli BL21 (DE3) and Top10F' cells were grown in LB broth at $37^{\circ} \mathrm{C}$ containing $100 \mathrm{mg} / \mathrm{ml}$ ampicillin. The vector pET-20b (Novagen, USA) was employed as a cloning and expression vector. The $\beta$-xylosidases XlnD, Tth XyB3, Tth Xyl and Tpe Xln3 and the $\beta$-glucosidase Tpebg3 were prepared by the Microbial Technology Research Laboratory, Nanjing Forestry University.

The substrates $p$ NPX, $p$ NP- $\beta$-D-glucopyranoside, $p$ NP$\beta$-D-galactopyranoside, $p$ NPR, $p$ NPAF and $p$ NPAP were purchased from Sigma (USA). The sugar xylobiose was purchased from Aladdin (China). Notoginsenoside R1 (> 98\% Purity, HPLC), ginsenoside Rg1 (>98\% Purity, HPLC), ASI ( $>98 \%$ Purity, HPLC) and CA (> 98\% Purity, HPLC) were purchased from the Chendu Institute of Biology, CAS (www.cdmust.com).

\section{DNA manipulation}

The DNA was manipulated following standard operating procedures. The Gel Extraction Kit and Plasmid Kit (Qiagen, USA) were used for purifying the PCR products and plasmids. The DNA restriction endonucleases $\mathrm{BamHI}$ and $X h o \mathrm{I}$, the T4 DNA ligase and the Ex-Taq restriction polymerase were purchased from TaKaRa (China). The DNA transformation was manipulated by electroporation using a Bio-Rad Gene Pulser (USA). 


\section{Plasmid constructions}

The $\beta$-xylosidase encoded gene $x \ln -D T$ (accession number: KX449145) with a size of approximately 1500 bp was amplified from Dictyoglomus thermophilum DSM 3960 genomic DNA by PCR with the primers $x \ln$-DT-f (CGCGGATCCATGAACCATATAAAGATTGAAA) and $x \ln -D T$-r (CCGCTCGAGATATCCACCTGGTATTTTGC TATC). The restriction enzyme sites were the underlined sequences. The amplified PCR products were then digested with $\mathrm{BamHI}$ and $\mathrm{XhoI}$ endonucleases and subcloned into the pET-20b vector; finally, the expression plasmid pET$20 \mathrm{~b}-x \ln -D T$ was obtained.

\section{Nucleotide sequence analysis of $x / n-D T$}

The nucleotide sequences of $x \ln -D T$ and the other known $\beta$-xylosidase genes were analyzed by the software Clustal 2.1. Databases were searched by using BLAST (http://www.blast.ncbi.nlm.nih.gov/Blast.cgi) at NCBI and against CAZy (www.cazy.org). Then, the neighborjoining (NJ) evolutionary tree was constructed by the software mega 7.0.

\section{Expression and purification of XIn-DT}

The recombinant plasmid, pET-20b- $x \ln -D T$, was transformed into E.coli BL21 (DE3), grown in LB broth containing $100 \mathrm{mg} / \mathrm{ml}$ ampicillin at $37{ }^{\circ} \mathrm{C}$ and induced to express recombinant Xln-DT by adding IPTG to a final concentration of $0.1 \mathrm{mM}$ and to an optical density, $\mathrm{OD}_{600}$, close to 0.8 ; the bacteria were further incubated at $28{ }^{\circ} \mathrm{C}$ for approximately $8 \mathrm{~h}$.

The recombinant cells (one liter) were harvested by centrifugation at $8,000 \times g\left(4{ }^{\circ} \mathrm{C}\right)$ for $20 \mathrm{~min}$, washed with distilled water several times and resuspended in $50 \mathrm{~mL}$ $1 \times$ binding buffer ( $\mathrm{pH} 7.9$ ). After sonication, the cell extracts were heat treated at $75{ }^{\circ} \mathrm{C}$ for $30 \mathrm{~min}$, cooled in an ice-bath and centrifuged at $10,000 \times \mathrm{g}\left(4{ }^{\circ} \mathrm{C}\right)$ for $30 \mathrm{~min}$. Finally, the supernatants were purified with an immobilized metal affinity column (Novagen, USA), and the enzyme protein was collected by eluting in $1 \times$ binding buffer ( $\mathrm{pH}$ 7.9). The purity of the target protein was canvassed by an SDS-PAGE gel, and the protein bands were analyzed by density scanning with an image analysis system (Bio-Rad, USA) [38]. The purified protein concentration was measured by the Bradford method using albumin from bovine serum as a standard.

\section{$\beta$-Xylosidase assay}

The substrate $p$ NPX was used for the $\beta$-xylosidase activity assay. The reaction mixture was contained with $10 \mu \mathrm{L}$ of $20 \mathrm{mM}$ substrate $p \mathrm{NPX}, 180 \mu \mathrm{L}$ of sodium phosphate buffer $(50 \mathrm{mM}, \mathrm{pH} 6.0)$ and $10 \mu \mathrm{L}$ of purified enzyme $(0.64 \mu \mathrm{g})$. After $10 \mathrm{~min}\left(75^{\circ} \mathrm{C}\right)$, the reaction was stopped by the addition of $600 \mu \mathrm{L} \mathrm{Na}_{2} \mathrm{CO}_{3}(1 \mathrm{M})$ [39]. The absorbance of the mixture was immediately measured at $405 \mathrm{~nm}$. The definition of one unit of $\beta$-xylosidase activity $(1 \mathrm{U})$ was consistent with the literature reference [36]. For every sample, the activity was measured three separate times.

The impact of temperature was measured by a standard assay over a range of temperatures $\left(60-90{ }^{\circ} \mathrm{C}\right)$ in sodium phosphate buffer (50 mM, pH 6.0). The optimum $\mathrm{pH}$ was evaluated by incubation at $75{ }^{\circ} \mathrm{C}$ for $10 \mathrm{~min}$ in $50 \mathrm{mM}$ sodium phosphate buffers with various $\mathrm{pH}$ values $(\mathrm{pH}$ 4.07.0). For the thermal stability analysis, the residual $\beta$ xylosidase activity was determined after the pre-incubation of enzymes $(0.64 \mu \mathrm{g})$ at a range of temperatures from 65 to $95{ }^{\circ} \mathrm{C}$ for $2 \mathrm{~h}$ (every $30 \mathrm{~min}$ ). The activity of the enzyme without pre-incubation was defined as $100 \%$. The $\mathrm{pH}$ stability of the enzyme was measured by determining the remaining activity after incubating the enzyme $(0.64 \mu \mathrm{g})$ in sodium phosphate buffer $(50 \mathrm{mM})$ from $\mathrm{pH} 4.0$ to 7.0 at $4{ }^{\circ} \mathrm{C}$. After $24 \mathrm{~h}$, the residual activity of the enzyme incubated at various $\mathrm{pH}$ values was measured. The purified enzyme $(0.64 \mu \mathrm{g})$ was incubated at temperatures ranging from 75 to $95{ }^{\circ} \mathrm{C}$ in sodium phosphate buffer $(50 \mathrm{mM}$, $\mathrm{pH}$ 6.0). The half-life was calculated from the first-order rate constants of inactivation, which were obtained from linear regressions in logarithmic coordinates [40]. The influence of various xylose concentrations $(250,500,750$, $1000,1500,2000,2500$ and $3000 \mathrm{mM}$ ) on the $\beta$-xylosidase activity was measured.

The effects of adding different ions and chemical reagents on the $\beta$-xylosidase activity of the purified enzyme $(0.64 \mu \mathrm{g})$ were examined by adding different metal ions into the aforementioned buffer. $\mathrm{Ni}^{2+}, \mathrm{Fe}^{3+}, \mathrm{Mn}^{2+}$, $\mathrm{Mg}^{2+}, \mathrm{Ca}^{2+}, \mathrm{K}^{+}, \mathrm{Zn}^{2+}, \mathrm{Al}^{3+}, \mathrm{Li}^{2+}, \mathrm{Na}^{+}, \mathrm{NH}_{4}{ }^{+}, \mathrm{Cu}^{2+}, \mathrm{Fe}^{2+}$, $\mathrm{Ba}^{2+}, \mathrm{Co}^{2+}$, and $\mathrm{Hg}^{2+}$ as well as the chemical reagents EDTA and PMSF were assayed at $1 \mathrm{mM}$ and $5 \mathrm{mM}$ of the final concentrations in the reaction mixture.

The effects of organic solvents on the $\beta$-xylosidase activity of the purified enzyme $(0.64 \mu \mathrm{g})$ were measured by adding 5, 10, 15, 20, 25 and 30\% organic solvents (methanol, ethanol or DMSO) to the mixture. The $\beta$-xylosidase enzyme Xln-DT was mixed with each solvent for $30 \mathrm{~min}$ at $75{ }^{\circ} \mathrm{C}$ before adding $p$ NPX to initiate the enzyme reaction. The activity of the enzyme without the metal ions, chemical reagents or organic solvents was defined as $100 \%$. Every experiment was performed in triplicate.

The substrate specificity of the purified enzyme $(0.64 \mu \mathrm{g})$ was tested by using $p \mathrm{NPX}, p \mathrm{NP}-\beta$-D-glucopyranoside, $p$ NP- $\beta$-D-galactopyranoside, $p$ NPR, $p$ NPAF and $p$ NPAP. The kinetic constant of the purified Xln-DT was measured by determining the initial rates at various $p$ NPX ending concentrations $(0.2,0.4,0.8,1,1.2,1.4,1.6,1.8,2,3,4,5,6$ and $8 \mathrm{mM}$ ) under standard reaction conditions.

\section{Xylobiose degradation}

The hydrolysis products from xylobiose by the purified Xln-DT were analyzed by TLC. Then, $10 \%$ xylobiose (wt/ 
vol) was dissolved in $100 \mu \mathrm{L}$ of citrate buffer solution (50 mM, pH 6.0) and incubated at $75{ }^{\circ} \mathrm{C}$ for $3 \mathrm{~h}$ with the addition of $1 \mathrm{U}$ Xln-DT $\beta$-xylosidase. The reaction was terminated by heating in boiling water for $10 \mathrm{~min}$. The hydrolysis products were analyzed by TLC on a silica gel plate (G254, Qingdao, China) using the solvent system containing n-butanol, ethanol and water (5:3:2, v/v/v) and were visualized using the orcinol sulfuric acid reagent.

\section{Enzymatic transformation of notoginsenoside R1 and ASI} For notoginsenoside R1 as a substrate, the reaction mixture contained $1 \mathrm{~g} / \mathrm{L}$ notoginsenoside R1, $0.1 \mathrm{U}$ Xln-DT and sodium phosphate buffer ( $50 \mathrm{mM}, \mathrm{pH}$ 6.0), and it was incubated at $75{ }^{\circ} \mathrm{C}$ for $30 \mathrm{~min}$ and then terminated by the addition of $400 \mu \mathrm{L}$ methanol. For ASI as a substrate, the reaction mixture contained $1 \mathrm{~g} / \mathrm{L}$ ASI, $0.5 \mathrm{U}$ Xln-DT, $1 \mathrm{U}$ Tpebg3 and sodium phosphate buffer (50 mM, pH 6.0), and it was incubated at $75{ }^{\circ} \mathrm{C}$ for $3 \mathrm{~h}$ and then terminated by the addition of $400 \mu \mathrm{L}$ methanol. The methanol extract of this material was analyzed by HPLC.

The notoginsenoside R1 and ginsenoside Rg1 were analyzed using an Agilent HPLC 1260 system (USA) and a C18 column $(4.6 \times 250 \mathrm{~mm}$; i.d., 5 m; S.No. USNH017518, USA) with distilled water (A) and acetonitrile (B) as the mobile phase, with a gradient elution of $20 \%$ (B) from 0 to $3 \mathrm{~min}$ and 20-60\% (B) from 3 to $28 \mathrm{~min}$. The injection volume was $5 \mu \mathrm{L}$ for each sample, the flow rate was $0.4 \mathrm{~mL} /$ min, and the detection was carried out by monitoring the absorbance at $203 \mathrm{~nm}$. The ASI and CA were also analyzed using the same system and column described above, with distilled water (A) and acetonitrile (B) as the mobile phase, with $\mathrm{A} / \mathrm{B}$ ratios of 40:60 from 0 to $16 \mathrm{~min}$; the detection was performed by monitoring the ELSD. The injection volume was $10 \mu \mathrm{L}$ for each sample, the flow rate was $1 \mathrm{~mL} /$ min, the gas flow rate was $2.1 \mathrm{~L} / \mathrm{min}$, and the ELSD drift tube temperature was $90{ }^{\circ} \mathrm{C}$.

\section{Results}

Cloning and sequencing of the $\beta$-xylosidase gene $x / n-D T$ According to the analysis of the complete genome sequence of Dictyoglomus thermophilum DSM 3960, a protein with possible $\beta$-xylosidase activity (GenBank accession No. KX449145) encoded 502 amino acids with a full-length of $1509 \mathrm{bp}$ and belonged to GH 39. To investigate the evolutionary relationship among the $\beta$-xylosidases, the phylogenetic trees were constructed by using the neighbor-joining method. The NJ trees revealed that there were seven clades, with each clade composed of a separated monophyletic group (Fig. 1). Clade I contained GH $3 \beta$-xylosidases from bacteria, archaea and fungi, Clade II contained GH $39 \beta-$ xylosidases from several thermophilic bacteria, and Clade III to VII contained $\beta$-xylosidases that belonged to $\mathrm{GH} 43$, $120,30,54$ and 52 , and were almost all from bacteria. Among the $\beta$-xylosidases from Clade II (GH 39), the members of the thermophilic genus Dictyoglomus had a distant relationship with Thermoanaerobacterium. Hence, it was posited that their enzymatic characterizations might be different. As is well known, GH 39 family $\beta$-xylosidases display a typical $(\alpha / \beta)_{8}$-barrel and perform hydrolysis in a two-stage reaction that consists of glycosylation and watermediated deglycosylation steps. Based on the present database, it can be indicated that this protein could be a novel $\beta$-xylosidase that belongs to the GH 39 family.

The $\beta$-xylosidase gene $x \ln -D T$ was cloned from the genomic DNA of D.thermophilum DSM 3960 and subcloned into the expression vector pET-20b to generate the plasmid pET-20b-xln-DT. Then the recombinant plasmid pET-20b-xln-DT was finally transformed into $E$. coli BL21 (DE3) and expressed with $0.1 \mathrm{mM}$ IPTG. The activity of the recombinant $\beta$-xylosidase was approximately $2.3 \mathrm{U} / \mathrm{mL}$ in $\mathrm{LB}$ medium.

\section{Purification and characterization of recombinant XIn-DT $\beta$-xylosidase}

For the biochemical characterization of the recombinant $\beta$-xylosidase, the crude $\beta$-xylosidase was purified by all the purification preparations. The crude $\beta$-xylosidase was given a single band on a $12 \%$ SDS-PAGE gel, and the MW of the enzyme was slightly more than $55 \mathrm{kDa}$ without the other bands (Fig. 2), which was similar to the theoretical MW of the monomer $(58.7 \mathrm{kDa})$. The specific activity of the purified Xln-DT was 2.9-fold higher than that of the crude enzyme with a purification yield of $52.6 \%$ (Table 1 ).

The enzymatic properties of the purified $\beta$-xylosidase Xln-DT were characterized. The optimal $\mathrm{pH}$ for Xln-DT was measured to be 6.0 . The enzyme showed over $80 \%$ of the maximum activity at a $\mathrm{pH}$ from 5.0 to 6.5 (Fig. 3a). Moreover, the novel $\beta$-xylosidase showed good stability after being treated in sodium phosphate buffers at different $\mathrm{pH}$ levels for $24 \mathrm{~h}$ (Fig. 3a). The optimal temperature for Xln-DT was $75{ }^{\circ} \mathrm{C}$. The enzyme showed more than $80 \%$ of the maximum activity at temperatures from $65{ }^{\circ} \mathrm{C}$ to $85{ }^{\circ} \mathrm{C}$ (Fig. 3b). Thermostability assays indicated that Xln-DT residual activity was above $60 \%$ of its initial activity at $65-85^{\circ} \mathrm{C}$ when tested at $\mathrm{pH} 6.0$ for $2 \mathrm{~h}$ (Fig. 3c). The kinetics of thermal inactivation were determined by incubating the enzyme at temperatures ranging from $75^{\circ} \mathrm{C}$ to $95^{\circ} \mathrm{C}$ for $3 \mathrm{~h}$. As shown in Fig. 3d, the half-life of the recombinant $\beta$-xylosidase Xln-DT was approximately $29 \mathrm{~h}$ at $75{ }^{\circ} \mathrm{C}$. At $95{ }^{\circ} \mathrm{C}$, the half-life was approximately $1 \mathrm{~h}$. In addition, Xln-DT had an unusually high tolerance to inhibition by xylose, up to $1 \mathrm{M}$ xylose, which did not affect the Xln-DT activity, and $60 \%$ of the relative activity was reserved in $3 \mathrm{M}$ xylose (Fig. 4).

The effects of the chemical reagents and metal ions on the enzyme activities of Xln-DT are shown in Table 2. The activity of Xln-DT was exceedingly inhibited by $\mathrm{Hg}^{2+}$ and 


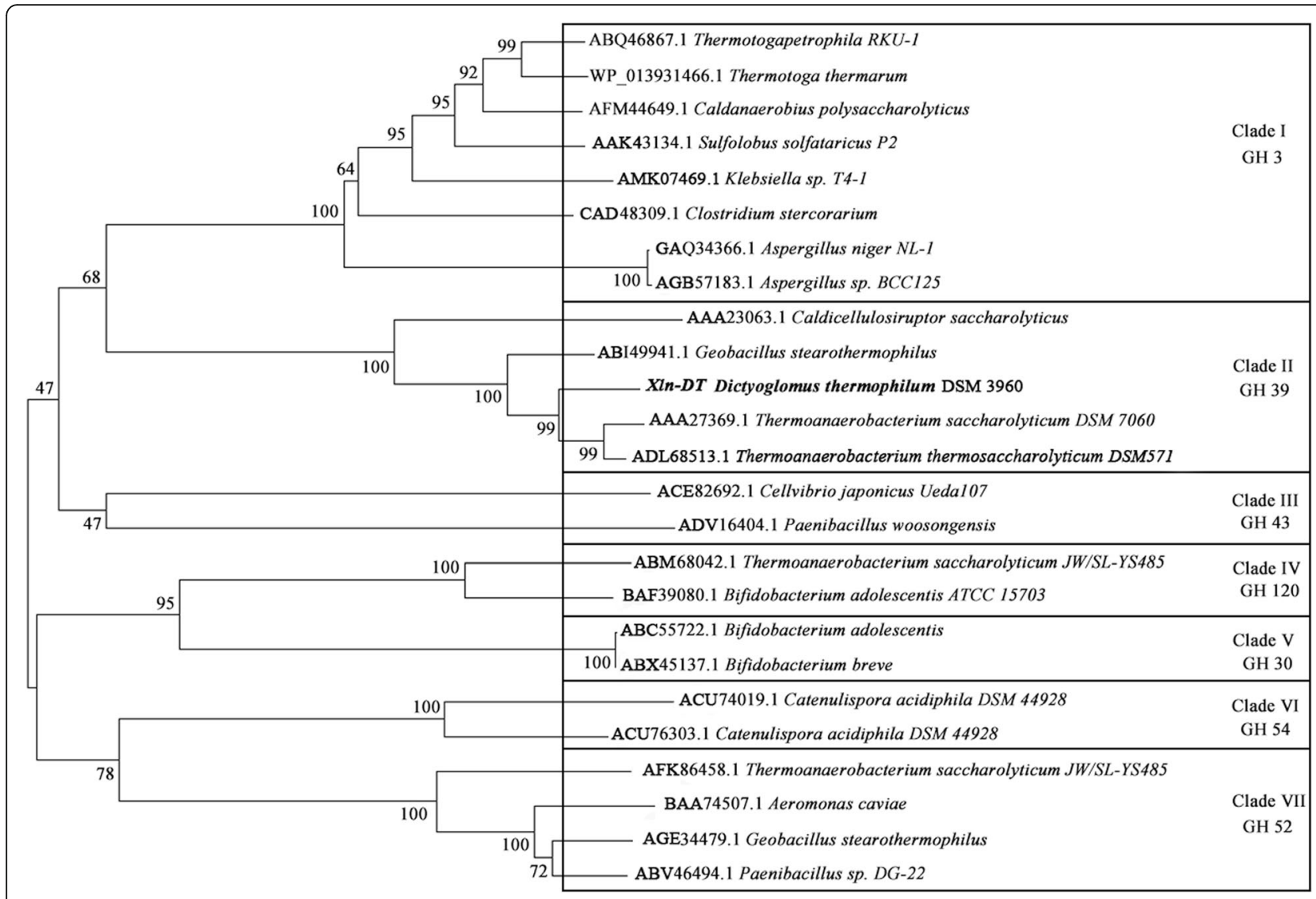

Fig. 1 Neighbor-Joining (NJ) tree results from analysis of the XIn-DT $\beta$-xylosidase of 25 amino acid sequences. (Numbers on nodes correspond to percentage bootstrap values for 1000 replicates)

$\mathrm{Cu}^{2+}$. Most of the other divalent metal cations had dissimilar effects on the activity of Xln-DT. In particular, the activity of Xln-DT, which was observably increased by $\mathrm{Fe}^{2+}, \mathrm{Fe}^{3+}$ and $\mathrm{Mn}^{2+}$, was similar to the alpha-mannosidase from the hen oviduct [41]. In addition, we incubated XlnDT with $\mathrm{Fe}^{2+}$ at $75^{\circ} \mathrm{C}$ for $3 \mathrm{~h}$. The results showed that $\mathrm{Fe}^{2+}$ improved the thermostability of Xln-DT at $75{ }^{\circ} \mathrm{C}$. The $\beta$ xylosidase activity of Xln-DT with $5 \mathrm{mM} \mathrm{Fe}{ }^{2+}$ remained at over $300 \%$ after $3 \mathrm{~h}$ of incubation at $75{ }^{\circ} \mathrm{C}$, while the XlnDT without any metal ions only retained $80 \%$ activity. In addition, organic solvents such as methanol, ethanol and DMSO also affected the enzyme activity. The residual enzyme activity was over $100 \%$, with $20 \%$ methanol or $10 \%$ ethanol. With the increasing concentrations of organic solvent, the enzyme activity was inhibited slowly.

The substrate specificity of Xln-DT was measured by using $1.0 \mathrm{mM}$ substrates (Table 3). The results illustrated that Xln-DT has a high activity toward $p$ NPX and a lower activity against $p \mathrm{NP}-\beta$-D-glucopyranoside, while no other glycosidase activity was detected against $p$ NP- $\beta$-D-galactopyranoside, $p$ NPAF, $p$ NPAP and $p$ NPR. The values of $K_{m}$ and $V_{\max }$ were $1.66 \mathrm{mM}$ and $78.46 \mathrm{U} / \mathrm{mg}$, respectively, with $p \mathrm{NPX}$ as the substrate. The kinetic parameters were measured from Lineweaver-Burk plots. These results suggest that Xln-DT has highly specific activity toward residual xylose.

\section{Xylobiose hydrolyzation of XIn-DT}

Xylobiose was incubated with purified Xln-DT $\beta$ xylosidase and examined using TLC (Fig. 5). After $3 \mathrm{~h}$, all the xylobiose tested was completely degraded to $x y-$ lose. This result indicates that this cloned enzyme is a true $\beta$-xylosidase with hydrolytic activity against short xylooligosaccharides.

\section{Biotransformation of notoginsenoside R1 and ASI by XIn-DT}

The biotransformation pathway from notoginsenoside R1 to ginsenoside $\operatorname{Rg} 1$ cleaved the outer xylose moiety at position C-6 of notoginsenoside R1 via $\beta$-xylosidase (Additional file 1: Figure S1). The biotransformation pathway from ASI to CA cleaved the outer glucose moiety at position $\mathrm{C}-6$ and the xylose moiety at position $\mathrm{C}-3$ of ASI via $\beta$-glucosidase and $\beta$-xylosidase, respectively 


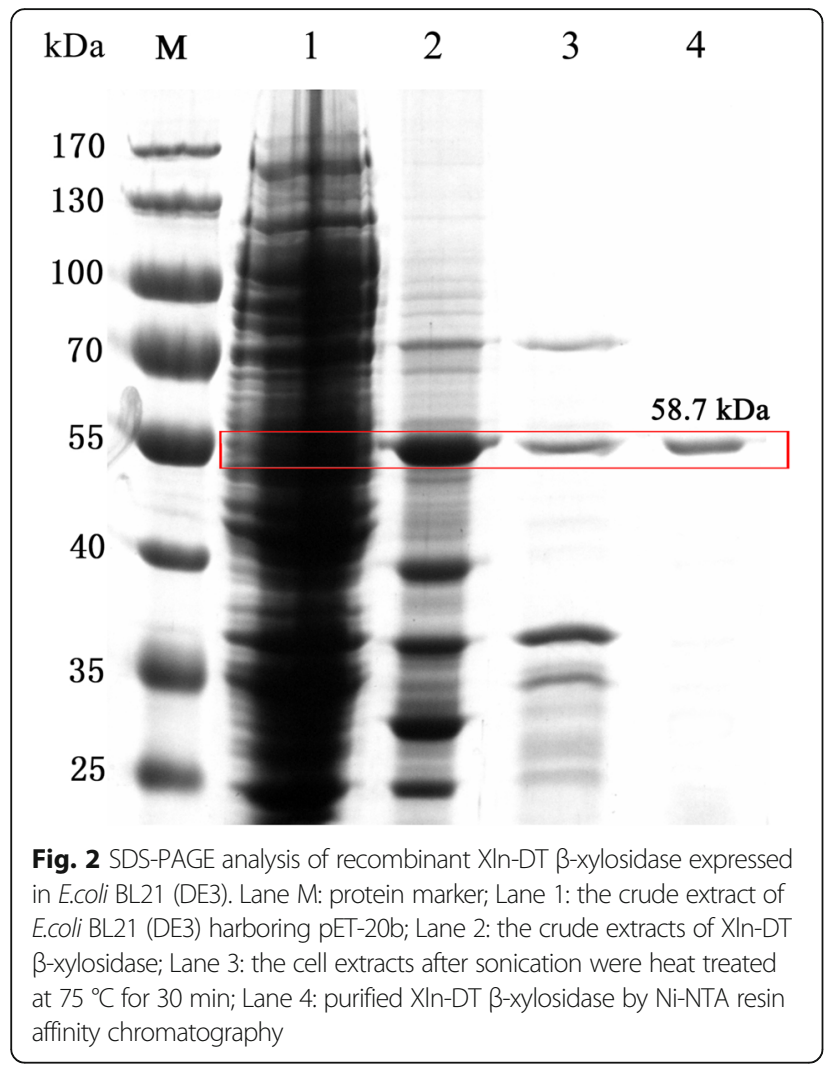

(Additional file 1: Figure S2). As shown in Fig. 6, three GH 3 family $\beta$-xylosidases Tth XyB3, Tpe Xln3 and $\mathrm{X} \ln \mathrm{D}$ from Thermotoga thermarum DSM 5069, Thermotoga petrophila DSM 13995 and Aspergillus niger $N L-1$, respectively, one GH 120 family $\beta$-xylosidase Tth Xyl from Thermoanaerobacterium thermosaccharolyticum DSM 571 and Xln-DT (GH 39) were selected to biotransform notoginsenoside R1 and ASI. Only the $\beta$ xylosidase Xln-DT from GH 39 family had 100 and 88 . $9 \%$ of the biotransformation rate for notoginsenoside R1 and ASI (Additional file 1: Figures S3 and S4). A total of $1 \mathrm{~g} / \mathrm{L}$ of notoginsenoside R1 was converted into $0.86 \mathrm{~g} / \mathrm{L}$ of ginsenoside $\mathrm{Rg} 1$ after $30 \mathrm{~min}$, with a corresponding molar conversion yield of $100 \%$ in total. A total of $1 \mathrm{~g} / \mathrm{L}$ of ASI was converted into $0.36 \mathrm{~g} / \mathrm{L}$ of CA after $3 \mathrm{~h}$, with a corresponding molar conversion yield of $88.9 \%$ in total.

\section{Discussion}

According to the database, more than 130 families were classified as glycoside hydrolases. Through the GenBank blast program, $\beta$-xylosidase Xln-DT belonged to the GH 39 family. This enzyme has the highest sequence similarity of $87 \%$ with $\beta$-xylosidase from Caldicellulosiruptor saccharolyticus (GenBank accession No. WP_049754849. 1 ) and shares a $72 \%$ similarity with the $\beta$-xylosidase from Thermoanaerobacterium thermosaccharolyticum (GenBank accession No. WP_013297482.1). The phylogenetic analysis showed that Xln-DT had a distant relationship with other $\beta$-xylosidases belonging to the GH 39 family. This paper is the first report on the purification and biochemical characterization of Xln-DT $\beta$-xylosidase from Dictyoglomus thermophilum.

Generally, fungal $\beta$-xylosidases have an optimal $\mathrm{pH}$ under 5.0, while bacterial $\beta$-xylosidases are active up to $\mathrm{pH}$ 7.0. In this paper, the optimum $\mathrm{pH}$ of the recombinant Xln-DT from Dictyoglomus thermophilum was found to be nearly neutral ( $\mathrm{pH}$ 6.0), which was similar to the $\beta$-xylosidase from Paecilomyces thermophila and GH 39 $\beta$-xylosidase from Caulobacter crescentus [26, 42]. The enzymatic characterization indicated that Xln-DT had a highly optimal temperature at $75^{\circ} \mathrm{C}$, which was higher than that observed for the $\beta$-xylosidases from Aspergillus niger, Sporotrichum thermophile and Caulobacter crescentus $[43,44]$. Moreover, Xln-DT had a preferable temperature tolerance under $85{ }^{\circ} \mathrm{C}$, which was similar to the thermostable GH $3 \beta$-xylosidase from Thermotoga thermarum [36]. In practical applications, an enzyme with high heat resistance is desirable preferentially because of its longer half-life $\left(29 \mathrm{~h}\right.$ for $\left.75^{\circ} \mathrm{C}\right)$ implying lower a consumption of the enzyme. The recombinant $\beta$-xylosidase has satisfactory $\mathrm{pH}$ and temperature stability, which is the favorable factor for the potential applications of the enzyme, such as in the biotransformation field.

As is well known, highly xylose-tolerant $\beta$-xylosidase has great potential in biochemical application fields because xylose is a strong inhibitor of $\beta$-xylosidase. Unfortunately, the majority of microbial $\beta$-xylosidases are sensitive to xylose. Table 4 summarizes the xyloseresistant ability from different organisms. Most $\beta$ xylosidases from fungi, such as Neurospora crassa and Aspergillus niger $B$ 03, display a $K_{i}$ for xylose below $2 \mathrm{mM}$. The bacterial $\beta$-xylosidases from Thermoanaerobacterium

Table 1 Purification of recombinant protein XIn-DT

\begin{tabular}{llllll}
\hline Purification step & Total activity(U) & Total protein $(\mathrm{mg})$ & Specific activity $(\mathrm{U} / \mathrm{mg})$ & Yield $(\%)$ & Fold purification \\
\hline Culture extract & 539.1 & 187.2 & 2.88 & 100 & 1 \\
Heat treatment $^{\mathrm{a}}$ & 392.3 & 67.3 & 5.83 & 72.8 & 2.02 \\
Ni affinity chromatography & 283.5 & 33.5 & 8.46 & 52.6 & 2.94 \\
\hline
\end{tabular}

Substrate for XIn-DT was $p$-Nitrophenyl- $\beta$-D-xylopyranoside

${ }^{a}$ The cell extracts after sonication were heat treated at $75^{\circ} \mathrm{C}$ for $30 \mathrm{~min}$, and then cooled in an ice bath, centrifuged at $8000 \mathrm{~g}$ for $10 \mathrm{~min}$ at $4{ }^{\circ} \mathrm{C}$ and the supernatant was kept 

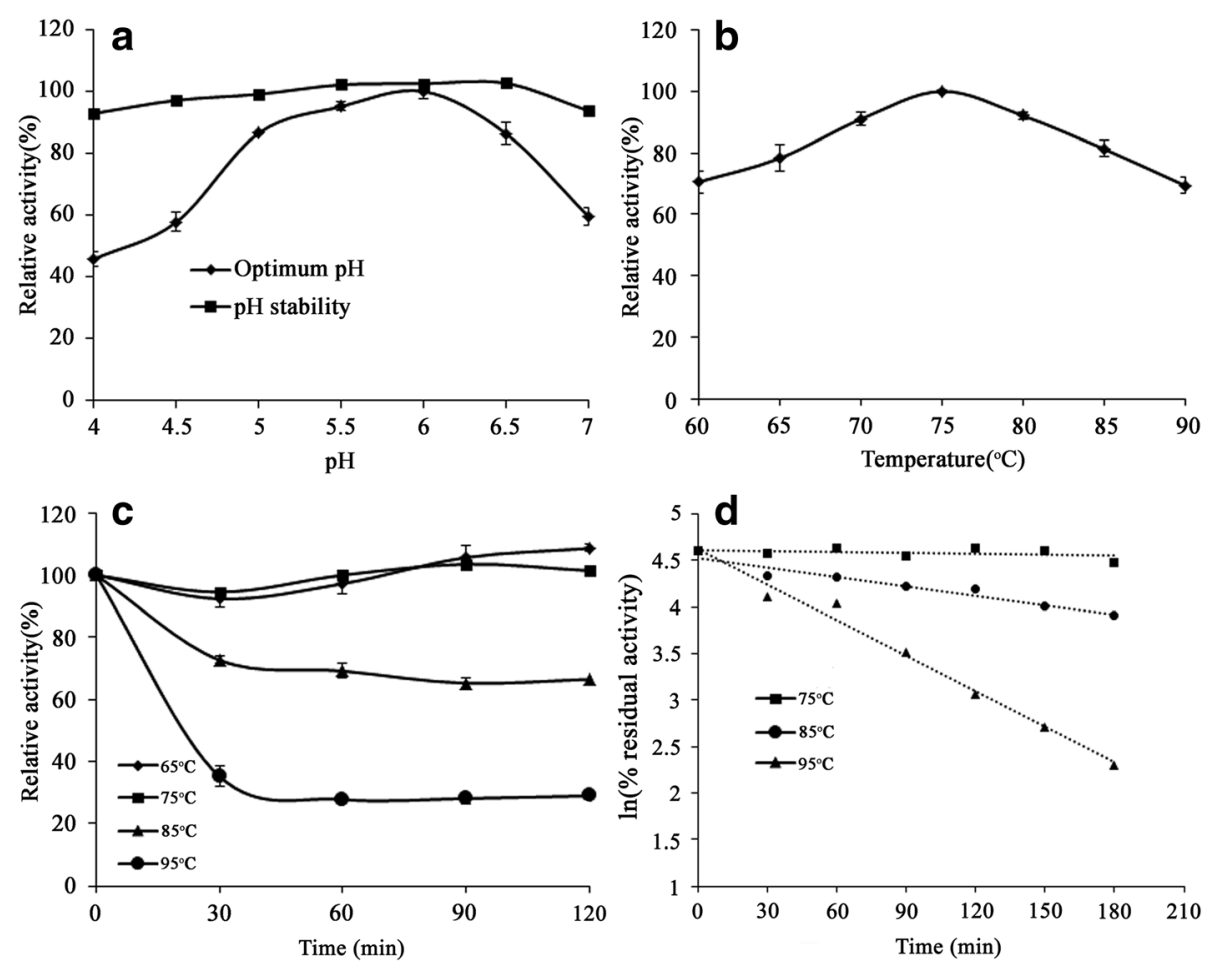

Fig. 3 Characterization of recombinant XIn-DT $\beta$-xylosidase. a Effects of optimum pH and pH stability of the enzyme XIn-DT; $\mathbf{b}$ Effect of temperature on XIn-DT activity; $\mathbf{c}$ The thermostability of the enzyme XIn-DT. The residual activity was monitored while the enzyme was incubated at $65^{\circ} \mathrm{C}$ (filled diamonds), $75{ }^{\circ} \mathrm{C}$ (filled squares), $85^{\circ} \mathrm{C}$ (flled triangles) and $95^{\circ} \mathrm{C}$ (filled circles). The maximum activity was defined as 100\%; $\mathbf{d}$ The kinetic of thermal inactivation of the enzyme XIn-DT at different temperatures ranging from $75^{\circ} \mathrm{C}$ to $95^{\circ} \mathrm{C}$ for several time intervals $\left(75^{\circ} \mathrm{C}\right.$ (filled squares), $85^{\circ} \mathrm{C}$ (filled circles), $95^{\circ} \mathrm{C}$ (filled triangles))

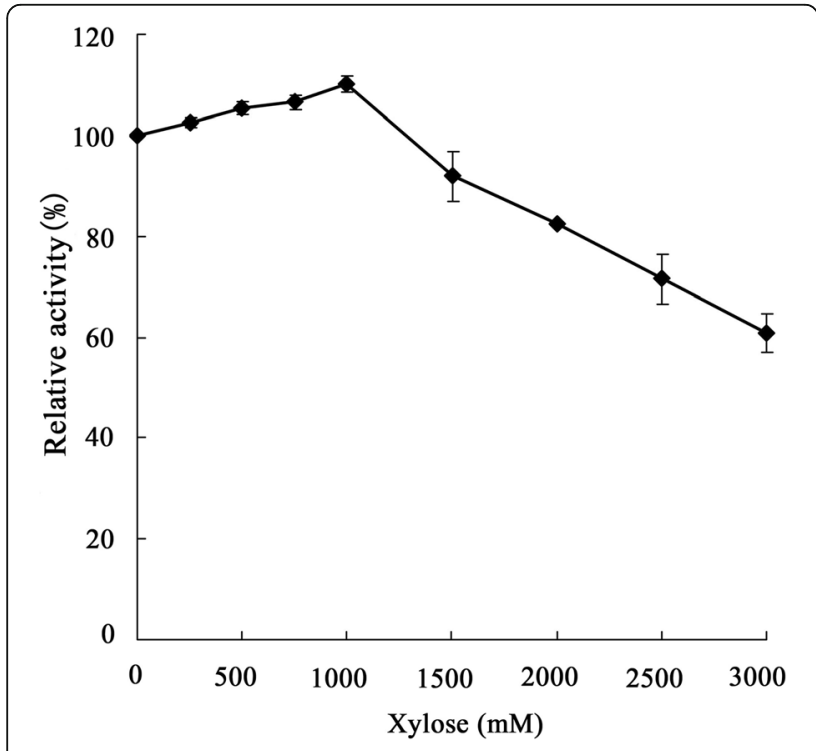

Fig. 4 Effects of xylose on XIn-DT $\beta$-xylosidase activity saccharolyticum, Thermotoga thermarum and Scytalidium thermophilum were insensitive to inhibition, ranging from $200 \mathrm{mM}$ to $1000 \mathrm{mM}$ xylose. In this study, it was surprising that Xln-DT had a very prominent tolerance to inhibition by xylose. There was no inhibition at $1 \mathrm{M}$ xylose, and there was a $40 \%$ inhibition at $3 \mathrm{M}$ xylose. Among the previously reported $\beta$-xylosidases, the $K_{i}$ for xylose of XlnDT $\beta$-xylosidase was the highest among those reported. At present, there is no literature to analyze the xylosetolerance mechanism of $\beta$-xylosidase, and only a few studies have reported the mechanism of glucose tolerance and stimulation of glucosidases [45]. The Xln-DT $\beta$-xylosidase with high xylose tolerance and stimulation suggested that some active sites at the entrance and middle of the substrate channel modulate the effects of xylose, which give the GH $39 \beta$-xylosidase a more prominent application potential in industries. The purified enzyme activity was measured by the presence of the tested ions. A $1 \mathrm{mM}$ (or $5 \mathrm{mM}$ ) concentration of $\mathrm{Cu}^{2+}$ and $\mathrm{Hg}^{2+}$ inhibited the enzyme activity significantly, which was relatively common for this enzyme from Paecilomyces thermophila [46]. The catalytic efficiency of the reaction system with $\mathrm{Fe}^{2+}$ and $\mathrm{Fe}^{3+}$ added at a $5 \mathrm{mM}$ final concentration was nearly 3.2- and 1.9- times higher, respectively, than enzymes without pre-incubation of the metal ions, 
Table 2 Effects of metal cations and reagents on the recombinant XIn-DT activity

\begin{tabular}{lll}
\hline Cation & \multicolumn{2}{l}{ Relative enzyme activity (\%) } \\
\cline { 2 - 3 } of reagent & $1 \mathrm{mM}$ & $5 \mathrm{mM}$ \\
\hline Contrast & 100 & 100 \\
PMSF & 112.4 & 114.5 \\
EDTA & 94.3 & 90.5 \\
$\mathrm{Al}^{3+}$ & 101.5 & 98.1 \\
$\mathrm{Cu}^{2+}$ & 48.1 & 39.9 \\
$\mathrm{Zn}^{2+}$ & 84.2 & 83.4 \\
$\mathrm{Ca}^{2+}$ & 98.3 & 87.1 \\
$\mathrm{Fe}^{2+}$ & 155.8 & 327.5 \\
$\mathrm{Fe}^{3+}$ & 99.8 & 199.3 \\
$\mathrm{Na}^{+}$ & 95.8 & 99.5 \\
$\mathrm{~K}^{+}$ & 101.3 & 101.4 \\
$\mathrm{Li}^{+}$ & 92.3 & 91.1 \\
$\mathrm{Mg}^{2+}$ & 102.8 & 97.1 \\
$\mathrm{NH}_{4}^{+}$ & 99.3 & 96.2 \\
$\mathrm{Mn}^{2+}$ & 98.3 & 115.8 \\
$\mathrm{Ba}^{2+}$ & 92.8 & 91.9 \\
$\mathrm{Hg}^{2+}$ & 35.3 & 35.1 \\
$\mathrm{Co}^{2+}$ & 95.8 & 89.6 \\
$\mathrm{Ni}^{2+}$ & 108.2 & 89.2 \\
\hline $\mathrm{Valu}^{2+}$ & &
\end{tabular}

Values shown were the mean of duplicate experiments, and the variation about the mean was below $5 \%$

indicating that the Fe ion could be the element of the catalytic active center and a stable factor for the structure of the aim protein. A $1 \mathrm{mM}$ or $5 \mathrm{mM}$ concentration of EDTA had no significant effect on the enzyme activity, which suggests that the chelating agent EDTA did not affect the $\beta$-xylosidase activity and was not essential for the catalytic activity of this enzyme. The organic modulator, PMSF ( $1 \mathrm{mM}$ or $5 \mathrm{mM}$ ), had slightly promoting role on enzyme activity. Moreover, $\mathrm{Fe}^{2+}$ and $\mathrm{Fe}^{3+}$ improved the thermostability of Xln-DT at $75^{\circ} \mathrm{C}$ for $3 \mathrm{~h}$, which indicated

Table 3 Relative activity of recombinant XIn-DT towards various chromogenic substrates as measured by pNP release at $75^{\circ} \mathrm{C}$

\begin{tabular}{|c|c|}
\hline Substrate $^{a}$ & Relative activity $(\text { mean } \% \pm S D)^{b}$ \\
\hline p-Nitrophenyl- $\beta$-D-xylopyranoside & $100 \pm 2.01$ \\
\hline p-Nitrophenyl- $\beta$-D-galactopyranoside & $N D^{c}$ \\
\hline p-Nitrophenyl-a-L-arabinofuranoside & ND \\
\hline p-Nitrophenyl-a-L-arabinopyranoside & ND \\
\hline p-Nitrophenyl-a-L-rhamnopyranoside & ND \\
\hline p-Nitrophenyl- $\beta$-D-glucopyranoside & $23.1 \pm 1.08$ \\
\hline
\end{tabular}

${ }^{a}$ Final concentration of each was $1.0 \mathrm{mM}$

${ }^{\mathrm{b}}$ The relative enzyme activity aganist $p$-Nitrophenyl- $\beta$-D-xylopyranoside was assumed to be $100 \%$

${ }^{c}$ Not determined, spectific activity is not determined by the analytical methods used in this study

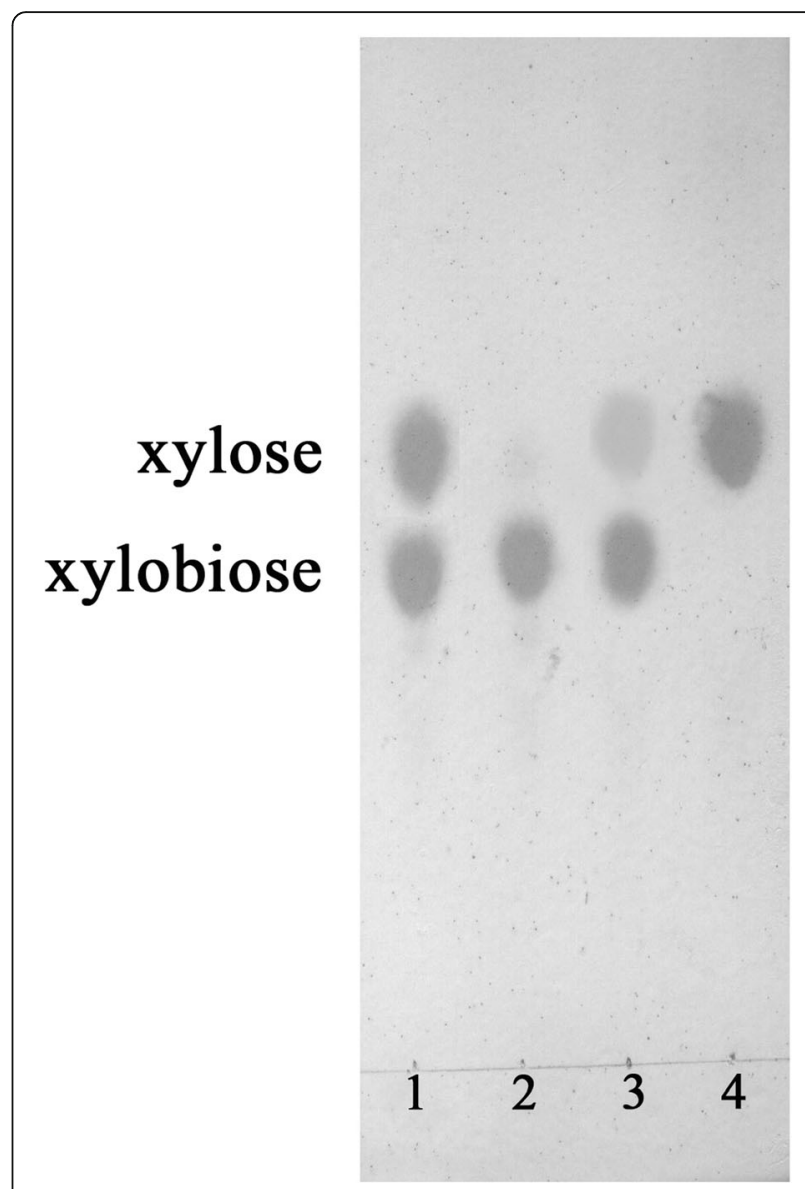

Fig. 5 TLC analysis of xylobiose hydrolyzed by XIn-DT. Lane1: Standards; Lane2: Xylobiose before reaction; Lane3: Xylobiose after reaction for 30 min; Lane4: Xylobiose after reaction for $3 \mathrm{~h}$

that this protein may have a metal-ion binding loop. By binding metal ions such as $\mathrm{Fe}^{2+}$ and $\mathrm{Fe}^{3+}$, the loop can keep the thermal stability of the protein structure. Since organic solvents have been used for solubilizing waterinsoluble substrates in enzymatic reactions, the enzyme with organic solvent resistance has a higher application value. As shown in Table 5, low concentrations of organic solvents, such as methanol, ethanol and DMSO, promoted enzyme activity, which was similar to the $\beta$-glucosidase from Thermotoga petrophila. This enzyme seemed to be tolerant to methanol and ethanol, since it was almost uninhibited in $20 \%$ of methanol and retained over $80 \%$ of its residual activity in the presence of $30 \%$ methanol. This level of tolerance was higher than that previously reported of $\beta$ xylosidases from Geobacillus thermodenitrificans [35]. The results indicated that the enzyme could be used in industrial applications in the presence of some organic solvents.

$\beta$-xylosidase is an exoglycosidase with the ability to degrade the non-reducing ends of xylooligosaccharides into xylose, which is one kind of hemicellulolytic enzyme. Compared with the other $\beta$-xylosidases, Xln-DT possessed 


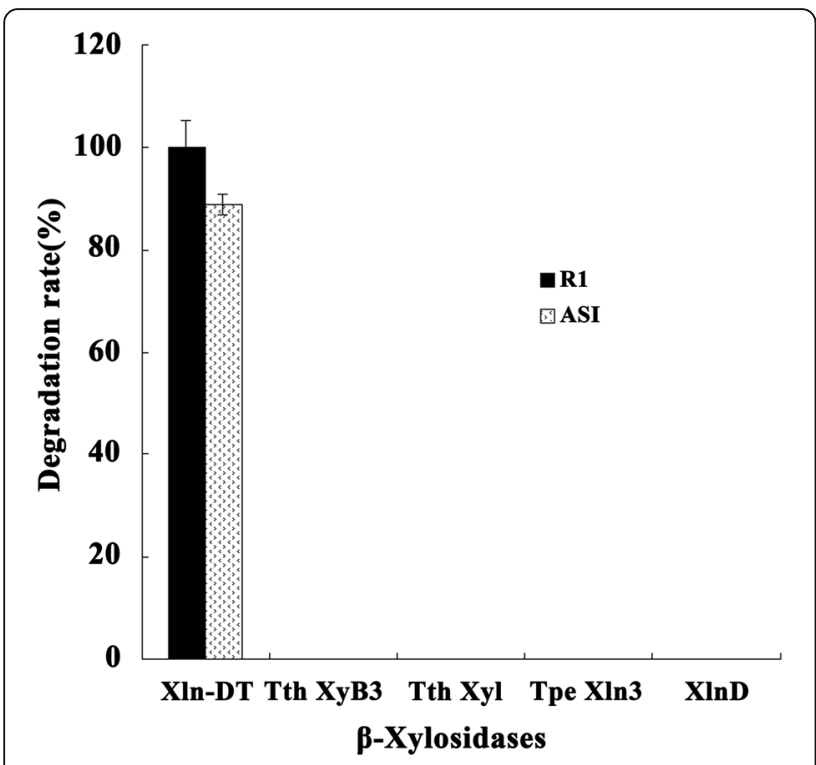

Fig. 6 Comparison of enzymatic conversion efficiency of notoginsenoside R1 and ASI to ginsenoside Rg1 and CA by $\beta$-xylosidases from different sources. (XIn-DT was from Dictyoglomus thermophilum DSM3960, Tth XyB3 was from Thermotoga thermarum DSM 5069, Tth Xyl was from Thermoanaerobacterium thermosaccharolyticum DSM 571, Tpe XIn3 was from Thermotoga petrophila DSM 13995, XInD was from Aspergillus niger NL-1)

higher efficiency in xylobiose hydrolysis. Reported $K_{m}$ values of other $\beta$-xylosidases for bacterial enzymes ranged from $0.018 \mathrm{mM}$ to $10 \mathrm{mM}$, while the $K_{m}$ values were normally over $1 \mathrm{mM}$ for fungal $\beta$-xylosidases. The $K_{m}$ and $V_{\max }$ values of Xln-DT for $p$ NPX were $1.66 \mathrm{mM}$ and 78 . $46 \mathrm{U} / \mathrm{mg}$, respectively, which were higher than the $\beta$ xylosidase from S.thermophilum with $65 \mathrm{U} / \mathrm{mg}$ [47]. Moreover, the capacity of the $\beta$-xylosidase to hydrolyze xylobiose was studied by using $10 \%$ xylobiose incubated with the purified enzyme at $75{ }^{\circ} \mathrm{C}$. After $3 \mathrm{~h}$, the xylobiose was completely hydrolyzed into xylose, which revealed the obvious ability to convert the XOs into xylose.

As is well known, conventional $\beta$-xylosidases are frequently used to hydrolyze the end bone of $\beta-1$, 4-linked
Table 5 The effects of organic solvent for the recombinant XInDT activity

\begin{tabular}{llll}
\hline $\begin{array}{l}\text { Final } \\
\text { concentration of organic } \\
\text { solvent (\%) }\end{array}$ & \multicolumn{3}{l}{ Relative enzyme activity (\%) } \\
\cline { 2 - 4 } & Methanol & Ethanol & DMSO \\
\hline 0 & 100 & 100 & 100 \\
5 & 110.5 & 115.6 & 90.1 \\
10 & 118.7 & 100.3 & 82.2 \\
15 & 118.5 & 87.6 & 68.6 \\
20 & 113.7 & 76.4 & 63.9 \\
25 & 88.5 & 58.6 & 56.5 \\
30 & 63.4 & 41.1 & 36.2 \\
\hline
\end{tabular}

Values shown were the mean of duplicate experiments, and the variation about the mean was below $5 \%$

xylopyranosyl. However, for notoginsenoside R1 and ASI, it was the 1, 2-glycosidic bond. According to this paper, only Xln-DT could cleave the outer xylose moiety at position C-6 of the notoginsenoside R1 and ASI, which indicated that it had highly specificity in biotransforming notoginsenoside R1 and ASI to ginsenoside Rg1 and $\mathrm{CA}$, without attacking the other glycosidic linkages. Although ginsenoside Rg1 and CA could be prepared by traditional methods, the yield was low, and it was time and money consuming. In addition, ginsenoside Rg1 and CA were accompanied with some by-products by traditional methods, which greatly impede later purification. Taken together, as a clean and green technology, biotransformation with specific enzymes showed the highest efficiency and specificity. All these results suggest that this recombinant Xln-DT has great potential for industrial applications, especially for bio-transformation to produce natural medicine.

\section{Conclusions}

In this paper, a novel $\beta$-xylosidase, Xln-DT, from Dictyoglomus thermophilum DSM 3960 was cloned and expressed in E. coli BL21. The phylogenetic analysis showed that Xln-DT had a distant relationship with other $\beta$-xylosidases belonging to the GH 39 family. The

Table 4 Xylose resistant ability of XIn-DT and $\beta$-xylosidase from other microorganisms

\begin{tabular}{|c|c|c|c|}
\hline No. & Organism & Xylose resistant ability & Reference \\
\hline 1 & Dictyoglomus thermophilum & $60 \%$ of its activity was retained in the presence of $3 \mathrm{M}$ xylose & This study \\
\hline 2 & Paecilomyces thermophila & a $K_{i}$ value of $139 \mathrm{mM}$ & {$[46]$} \\
\hline 3 & Aspergillus niger B 03 & a $K_{i}$ value of $1.857 \mathrm{mM}$ & {$[44]$} \\
\hline 4 & Thermotoga thermarum & a $K_{i}$ value of $1000 \mathrm{mM}$ & {$[36]$} \\
\hline 5 & Thermoanaerobacterium saccharolyticum & $70 \%$ of its activity was retained in the presence of $200 \mathrm{mM}$ xylose & {$[48]$} \\
\hline 6 & Scytalidium thermophilum & Xylose inhibits most $\beta$-xylosidase at concentrations up to 200 mM & {$[47]$} \\
\hline 7 & Neurospora crassa & a $K_{i}$ value of $1.72 \mathrm{mM}$ & {$[30]$} \\
\hline 8 & Humicola insolens & $K_{i}$ values for Xyl43A and Xy|43B were 79 and 292 mM, respectively. & {$[49]$} \\
\hline 9 & Aureobasidium pullulans CBS 135684 & a $K_{i}$ value of $18 \mathrm{mM}$ & {$[50]$} \\
\hline
\end{tabular}


enzymatic characterization displayed that Xln-DT had a high optimal temperature and a partially neutral $\mathrm{pH}$, and the thermostability was improved by the ion Fe. Most importantly, there was no inhibition at $1 \mathrm{M}$ xylose, and there was a $40 \%$ inhibition at $3 \mathrm{M}$ xylose. Compared with the other $\beta$-xylosidases, Xln-DT possessed higher efficiency in xylobiose hydrolysis and had efficiency for biotransforming notoginsenoside R1 and ASI by removing the 1, 2 glycosidic bond linked to the C-6 and C-3 carbons. This study indicates that recombinant Xln-DT would be suitable for producing natural medicine, such as ginsenoside $\operatorname{Rg} 1$ and $C A$.

\section{Additional file}

Additional file 1: Figure S1. Biotransformation pathway for production of ginsenoside Rg1 from notoginsenoside R1. Figure S2.

Biotransformation pathway for production of CA from ASI. Figure S3.

HPLC analysis of notoginsenoside R1 hydrolysis by XIn-DT. (a) Standards of notoginsenoside R1 and ginsenoside Rg1; (b-d) notoginsenoside R1 (1 g/L) incubated with XIn-DT for 0, 5 and $30 \mathrm{~min}$, respectively. Figure S4. HPLC analysis of ASI hydrolysis by XIn-DT. (a) Standards of ASI and CA; (b-d) ASI (1 $\mathrm{g} / \mathrm{L})$ incubated with XIn-DT and Tpebg3 for 0, 1 and $3 \mathrm{~h}$, respectively. (DOC $5520 \mathrm{~kb})$

\section{Abbreviations}

ASI: Astragaloside IV; CA: Cycloastragenol; E.coli: Escherichia coli; EDTA: Ethylenediaminetetraacetic acid; ELSD: Evaporative Light Scattering Detector; GH: Glycosyl hydrolase; HPLC: High performance liquid chromatography; IPTG: Isopropyl- $\beta$-D-thiogalactopyranoside; LB: Luria-Bertani; MW: Molecular weight; NJ: Neighbor-joining; PCR: Polymerase chain reaction; pNPAF: $p$-nitrophenyl-a-L-arabinofuranoside; pNPAP: $p$-nitrophenyl-a-Larabinopyranoside; pNPR: p-nitrophenyl-a-L-rhamnopyranoside; pNPX: pnitrophenyl- $\beta$-D-xylopyranoside; QC: Quality control; SDS-PAGE: Sodium dodecyl sulfate polyacrylamide gel electrophoresis; TLC: Thin-layer chromatography; XOs: Xylooligosaccharides

\section{Funding}

This study was funded by the National Key Research Development Program of China (Grant number 2017YFD0600805); the Forestry Achievements of Science and Technology to Promote Projects (Grant number [2017]10), the 11th Six Talents Peak Project of Jiangsu Province (Grant number 2014-JY-011) and the Priority Academic Program Development of Jiangsu Higher Education Institutions (PAPD).

\section{Availability of data and materials}

The data set supporting the results of this article are included within the article.

\section{Authors' contributions \\ QL designed and performed the experiments and drafted the manuscript. TW and ZPQ helped to performed purification and characterization. JJP and FT helped to analyze the biotransformation of ginsenoside Rg1 and CA and revise the manuscript. LGZ directed the over-all study and had given final approval of the version to be published. All authors read and approved the final manuscript.}

Ethics approval and consent to participate

Not applicable.

\section{Competing interests}

The authors declare that they have no competing interests.

\section{Publisher's Note}

Springer Nature remains neutral with regard to jurisdictional claims in published maps and institutional affiliations.

\section{Author details}

${ }^{1}$ Co-Innovation Center for Sustainable Forestry in Southern China, Nanjing Forestry University, 159 Long Pan Road, Nanjing 210037, China. ${ }^{2}$ College of Chemical Engineering, Nanjing Forestry University, 159 Long Pan Road, Nanjing 210037, China. ${ }^{3}$ Jiangsu Key Lab for the Chemistry \& Utilization of Agricultural and Forest Biomass, 159 Long Pan Road, Nanjing 210037, China. ${ }^{4}$ International Centre for Bamboo and Rattan, 8 Fu Tong East Street, Beijing 100714, China.

Received: 12 October 2017 Accepted: 24 April 2018

Published online: 21 May 2018

\section{References}

1. Nigam PS, Singh A. Production of liquid biofuels from renewable resources. Prog Energy Combustion Sci. 2011;37:52-68.

2. Zimbardi AL, Sehn C, Meleiro LP, Souza FH, Masui DC, Nozawa MS, Guimarães LH, Jorge JA, Furriel RP. Optimization of $\beta$-glucosidase, $\beta$ xylosidase and xylanase production by Colletotrichum graminicola under solid-state fermentation and application in raw sugarcane trash saccharification. Int J Mol Sci. 2013:14:2875.

3. Barr CJ, Mertens JA, Schall CA. Critical cellulase and hemicellulase activities for hydrolysis of ionic liquid pretreated biomass. Bioresour Technol. 2012; 104:480-5.

4. Sachslehner A, Haltrich D. Purification and some properties of a thermostable acidic endo- $\beta-1,4-d-m a n n a n a s e$ from Sclerotium (Athelia) rolfsii. FEMS Microbiol Lett. 1999;177:47-55.

5. Tabka MG, Herpoëlgimbert I, Monod F, Asther M, Sigoillot JC. Enzymatic saccharification of wheat straw for bioethanol production by a combined cellulase xylanase and feruloyl esterase treatment. Enzyme Microb Technol. 2006;39:897-902.

6. Ohta K, Fujimoto H, Fuiji S. Cell-associated $\beta$-xylosidase from Aureobasidium pullulans ATCC 20524: purification, properties, and characterization of the encoding gene. J Biosci Bioeng. 2010;110:152-7.

7. Zhang J, Siikaaho M, Puranen T, Ming T, Tenkanen M, Viikari L. Thermostable recombinant xylanases from Nonomuraea flexuosa and Thermoascus aurantiacus show distinct properties in the hydrolysis of xylans and pretreated wheat straw. Biotechnol Biofuels. 2011:4:12.

8. Goldbeck R, Gonçalves TA, Damásio ARL, Brenelli LB, Wolf LD, Paixão DAA Rocha GJM, Squina FM. Effect of hemicellulolytic enzymes to improve sugarcane bagasse saccharification and xylooligosaccharides production. J Mol Catalysis B Enzymatic. 2016;131:36-46.

9. Michelin M, Polizeli MDLTM, Ruzene DS, Silva DP, Ruiz HA, Vicente AA, Jorge $J A$, Terenzi HF, Teixeira JA. Production of xylanase and $\beta$-xylosidase from autohydrolysis liquor of corncob using two fungal strains. Bioprocess Biosyst Eng. 2012;35:1185-92.

10. Martins MP, Ventorim RZ, Coura RR, Maitan-Alfenas GP, Alfenas RF, Guimarães VM. The $\beta$-xylosidase from Ceratocystis fimbriata RM35 improves the saccharification of sugarcane bagasse. Biocatalysis Agric Biotechnol. 2018:13:291-8.

11. Jordan DB, Wagschal K. Properties and applications of microbial beta-Dxylosidases featuring the catalytically efficient enzyme from Selenomonas ruminantium. Appl Microbiol Biotechnol. 2010;86:1647-58.

12. Shin KC, Seo MJ, Oh DK. Characterization of $\beta$-xylosidase from Thermoanaerobacterium thermosaccharolyticum and its application to the production of ginsenosides Rg1 and Rh1 from notoginsenosides R1 and R2. Biotechnol Lett. 2014;36:2275-81.

13. Inoue H, Kitao C, Yano S, Sawayama S. Production of $\beta$-xylosidase from Trichoderma asperellum KIF125 and its application in efficient hydrolysis of pretreated rice straw with fungal cellulase. World J Microbiol Biotechnol. 2016;32:1-10.

14. Cheng W, Jing J, Wang Z, Wu D, Huang Y. Chondroprotective effects of Ginsenoside Rg1 in human osteoarthritis chondrocytes and a rat model of anterior cruciate ligament transection. Nutrients. 2017;9:263.

15. Zhao JH, Zhang QB, Liu B, Piao XH, Yan YL, Hu XG, Zhou K, Zhang YT, Feng NP. Enhanced immunization via dissolving microneedle array-based delivery system incorporating subunit vaccine and saponin adjuvant. Int J Nanomedicine. 2017;12:4763-72. 
16. Xie J, Zhao D, Zhao L, Pei J, Xiao W, Ding G, Wang Z. Overexpression and characterization of a $\mathrm{Ca}(2+)$ activated thermostable beta-glucosidase with high ginsenoside $\mathrm{Rb} 1$ to ginsenoside $20(\mathrm{~S})-\mathrm{Rg} 3$ bioconversion productivity. J Ind Microbiol Biotechnol. 2015;42:839-50.

17. Zhang R, Zhang BL, Xie T, Li GC, Tuo Y, Xiang YT. Biotransformation of rutin to isoquercitrin using recombinant a-L-rhamnosidase from Bifidobacterium breve. Biotechnol Lett. 2015;37:1257-64.

18. Sevimligür C, Onbaşılar I, Atilla P, Genç R, Cakar N, Deliloğlugürhan I, Bedir E. In vitro growth stimulatory and in vivo wound healing studies on cycloartanetype saponins of Astragalus genus. J Ethnopharmacol. 2011;134:844-50.

19. Chang HL, Kim JH. A review on the medicinal potentials of ginseng and ginsenosides on cardiovascular diseases. J Ginseng Res. 2014;38:161.

20. Attele AS, Wu JA, Yuan CS. Ginseng pharmacology: multiple constituents and multiple actions. Biochem Pharmacol. 1999;58:1685.

21. Valenzuela HF, Fuller T, Edwards J, Finger D, Molgora B. Cycloastragenol extends T cell proliferation by increasing telomerase activity. J Immunol. 2009;182.

22. Huang BM, Xiao SY, Chen TB, Xie Y, Luo P, Liu L, Zhou H. Purity assessment of ginsenoside $\mathrm{Rg} 1$ using quantitative $1 \mathrm{H}$ nuclear magnetic resonance. J Pharm Biomed Anal. 2017;139:193.

23. Ip FC, Ng YP, An HJ, Dai Y, Pang HH, Hu YQ, Chin AC, Harley CB, Wong YH, Ip NY. Cycloastragenol is a potent telomerase activator in neuronal cells: implications for depression management. Neurosignals. 2014;22:52-63.

24. Kim WY, Kim JM, Han SB, Lee SK, Kim ND, Park MK, Kim CK, Park JH. Steaming of ginseng at high temperature enhances biological activity. J Nat Prod. 2000;63:1702.

25. Bae EA, Han MJ, Kim EJ, Kim DH. Transformation of ginseng saponins to ginsenoside rh2 by acids and human intestinal bacteria and biological activities of their transformants. Arch Pharm Res. 2004;27:61-7.

26. Yang DC, Lin HQ, Liang Z, Ho-Bin K, Se-Hwa K, Se-Young K, Yeong-Deok N Conversion of Ginsenoside Rd to compound K by crude enzymes from Lactobacillus brevis LH8. J Ginseng Res. 2008;32:226-31.

27. White A, Rose DR. Mechanism of catalysis by retaining beta-glycosyl hydrolases. Curr Opin Struct Biol. 1997;7:645

28. Goujon T, Minic Z, El AA, Lerouxel O, Aletti E, Lapierre C, Joseleau JP, Jouanin L. AtBXL1, a novel higher plant (Arabidopsis thaliana) putative betaxylosidase gene, is involved in secondary cell wall metabolism and plant development. Plant J. 2003;33:677-90.

29. Czjzek M, Ben DA, Bravman T, Shoham G, Henrissat B, Shoham Y. Enzymesubstrate complex structures of a GH39 beta-xylosidase from Geobacillus stearothermophilus. J Mol Biol. 2005;353:838-46.

30. Kirikyali N, Connerton IF. Heterologous expression and kinetic characterisation of Neurospora crassa $\beta$-xylosidase in Pichia pastoris. Enzyme Microb Technol. 2014;57:63-8.

31. Patel H, Kumar AK, Shah A. Purification and characterization of novel bifunctional GH3 family $\beta$-xylosidase/ $\beta$-glucosidase from aspergillus Niger ADH-11. Int J Biol Macromol. 2018;109:1260-69.

32. Eneyskaya EV, Ivanen DR, Bobrov KS, Isaevaivanova LS, Shabalin KA, Savel'Ev AN, Golubev AM, Kulminskaya AA. Biochemical and kinetic analysis of the GH3 family beta-xylosidase from Aspergillus awamori X-100. Arch Biochem Biophys. 2007:457:225.

33. Mustafa G, Kousar S, Rajoka MI, Jamil A. Molecular cloning and comparative sequence analysis of fungal $\beta$-Xylosidases. AMB Express. 2016;6:30.

34. Lama L, Calandrelli V, Gambacorta A, Nicolaus B. Purification and characterization of thermostable xylanase and beta-xylosidase by the thermophilic bacterium Bacillus thermantarcticus. Res Microbiol. 2004;155:283-9.

35. Jain I, Kumar V, Satyanarayana T. Applicability of recombinant $\beta$-xylosidase from the extremely thermophilic bacterium Geobacillus thermodenitrificans in synthesizing alkylxylosides. Bioresour Technol. 2014;170:462-9.

36. Hao $S$, Xun L, Gu H, Yu Z, Huang Y, Wang L, Fei W. Biochemical properties of a novel thermostable and highly xylose-tolerant $\beta$-xylosidase/aarabinosidase from Thermotoga thermarum. Biotechnol Biofuels. 2013;6:27.

37. Zhao L, Xie J, Zhang X, Cao F, Pei J. Overexpression and characterization of a glucose-tolerant $\beta$-glucosidase from Thermotoga thermarum DSM 5069T with high catalytic efficiency of ginsenoside Rb1 to Rd. J Mol Catalysis B Enzymatic. 2013;95:62-9.

38. Laemmli UK. Cleavage of structural proteins during the assembly of the head of bacteriophage T4. Nature. 1970;227:680-5.

39. Shao W, Wiegel J. Purification and characterization of a thermostable betaxylosidase from Thermoanaerobacter ethanolicus. J Bacteriol. 1992;174:5848-53.

40. Ge L, Chen A, Pei J, Zhao L, Fang X, Ding G, Wang Z, Xiao W, Tang F. Enhancing the thermostability of a-L-rhamnosidase from Aspergillus terreus and the enzymatic conversion of rutin to isoquercitrin by adding sorbitol. BMC Biotechnol. 2017;17:21.

41. Yamashiro K, Itoh H, Yamagishi M, Natsuka S, Mega T, Hase S. Purification and characterization of neutral alpha-mannosidase from hen oviduct: studies on the activation mechanism of Co2+. J Biochem. 1997;122:1174-81.

42. Corrêa JM, Graciano L, Abrahão J, Loth EA, Gandra RF, Kadowaki MK, Henn C, Simão RDCG. Expression and characterization of a GH39 $\beta$-Xylosidase ॥ from Caulobacter crescentus. Appl Biochem Biotechnol. 2012;168:2218-29.

43. Katapodis P, Nerinckx W, Claeyssens M, Christakopoulos P. Purification and characterization of a thermostable intracellular $\beta$-xylosidase from the thermophilic fungus Sporotrichum thermophile. Process Biochem. 2006;41:2402-9.

44. Delcheva G, Dobrev G, Pishtiyski I. Performance of Aspergillus niger B 03 Bxylosidase immobilized on polyamide membrane support. J Mol Catalysis B Enzymatic. 2008;54:109-15.

45. Yang $Y$, Zhang $X$, Yin Q, Fang W, Fang Z, Wang $X$, Zhang $X$, Xiao Y. A mechanism of glucose tolerance and stimulation of GH1 $\beta$-glucosidases. Sci Rep. 2015;5:17296.

46. Yan QJ, Wang L, Jiang ZQ, Yang SQ, Zhu HF, Li LT. A xylose-tolerant betaxylosidase from Paecilomyces thermophila: characterization and its co-action with the endogenous xylanase. Bioresour Technol. 2008;99:5402.

47. Zanoelo FF, Terenzi HF, Jorge JA. Purification and biochemical properties of a thermostable xylose-tolerant $\beta$-D-xylosidase from Scytalidium thermophilum. J Ind Microbiol Biotechnol. 2004;31:170-6.

48. Shao W, Xue Y, Wu A, Kataeva I, Pei J, Wu H, Wiegel J. Characterization of a novel $\beta$-Xylosidase, XylC, from Thermoanaerobacterium saccharolyticum JW/ SL-YS485. Appl Environ Microbiol. 2011;77:719-26.

49. Yang $X$, Shi P, Huang H, Luo H, Wang Y, Zhang W, Yao B. Two xylosetolerant $\mathrm{GH} 43$ bifunctional $\beta$-xylosidase/a-arabinosidases and one GH11 xylanase from Humicola insolens and their synergy in the degradation of xylan. Food Chem. 2014;148:381-7.

50. Bankeeree W, Akada R, Lotrakul P, Punnapayak H, Prasongsuk S. Enzymatic hydrolysis of black liquor Xylan by a novel xylose-tolerant, thermostable $\beta$ Xylosidase from a tropical strain of Aureobasidium pullulans CBS 135684. Appl Biochem Biotechnol. 2018;184:919-34.

\section{Ready to submit your research? Choose BMC and benefit from:}

- fast, convenient online submission

- thorough peer review by experienced researchers in your field

- rapid publication on acceptance

- support for research data, including large and complex data types

- gold Open Access which fosters wider collaboration and increased citations

- maximum visibility for your research: over $100 \mathrm{M}$ website views per year

At BMC, research is always in progress.

Learn more biomedcentral.com/submissions 